\title{
High Glucose Enhances Store-Operated Calcium Entry by Upregulating ORAI/STIM via Calcineurin-NFAT Signalling
}

\author{
Nikoleta Daskoulidou ${ }^{1}$, Bo Zeng ${ }^{1}$, Lisa M. Berglund ${ }^{2}$, Hongni Jiang ${ }^{1}$, Gui-Lan Chen ${ }^{1}$, Olga \\ Kotova $^{2}$, Sunil Bhandari ${ }^{3}$, James Ayoola ${ }^{1}$, Steven Griffin ${ }^{4}$, Stephen L. Atkin ${ }^{1}$, Maria F \\ Gomez ${ }^{2}$, Shang-Zhong $\mathrm{Xu}^{1 *}$
}

${ }^{1}$ Centre for Cardiovascular and Metabolic Research, Hull York Medical School, University of Hull, HU6 7RX, UK

${ }^{2}$ Department of Clinical Sciences in Malmö, Lund University, Sweden

${ }^{3}$ Department of Renal Medicine and Hull York Medical School, Hull Royal Infirmary, Hull and East Yorkshire Hospitals NHS Trust, UK

${ }^{4}$ Department of Cardiac Surgery, Castle Hill Hospital, Hull and East Yorkshire Hospitals NHS Trust, UK

* Correspondence:

Dr. S.Z. Xu

Centre for Cardiovascular and Metabolic Research, Hull York Medical School University of Hull, Hull, HU6 7RX, United Kingdom

Tel: (44) 01482 465372, Fax: (44) 01482 465390, Email: sam.xu@ hyms.ac.uk

Running title: High Glucose Upregulates ORAI/STIM by $\mathrm{Ca}^{2+}$ Signalling

Total word count (3381), Figure (5), Supplementary figures (3) , + Supp Table (2) 


\begin{abstract}
ORAI and STIM are store-operated channel molecules that play essential roles in human physiology through a coupling mechanism of internal $\mathrm{Ca}^{2+}$ store to $\mathrm{Ca}^{2+}$ influx. However, the roles of ORAI and STIM in vascular endothelial cells under diabetic conditions remain unknown. Here we investigated expression and signalling pathways of ORAI and STIM regulated by high glucose or hyperglycaemia using in vitro cell models, in vivo diabetic mice and tissues from patients. We found that ORAI1-3 and STIM1-2 were ubiquitously expressed in human vasculatures. Their expression was upregulated by chronic treatment with high glucose (HG, $25 \mathrm{mM}$ D-glucose), which was accompanied by enhanced store-operated $\mathrm{Ca}^{2+}$ influx in vascular endothelial cells. The increased expression was also observed in the aortae

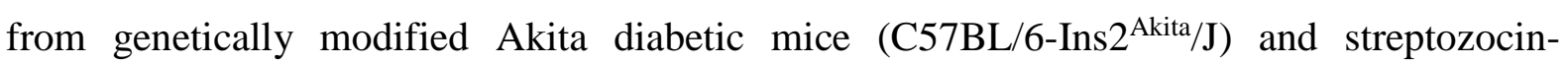
induced diabetic mice, and aortae from diabetic patients. HG-induced upregulation of ORAI and STIM genes was prevented by the calcineurin inhibitor cyclosporin A and NFATc3 siRNA. Additionally, in vivo treatment with the NFAT inhibitor A-285222 prevented the gene upregulation in Akita mice. However, HG had no direct effects on ORAI1-3 currents and the channel activation process through cytosolic STIM1 movement in the cells coexpressing STIM1-EYFP/ORAIs. We concluded that upregulation of STIM/ORAI through $\mathrm{Ca}^{2+}$-calcineurin-NFAT pathway is a novel mechanism causing abnormal $\mathrm{Ca}^{2+}$ homeostasis and endothelial dysfunction under hyperglycaemia.
\end{abstract}

Key Words: Hyperglycemia, calcium channels, ORAI, STIM1, diabetes mellitus, calcineurin, NFATc transcription factors 


\section{Introduction}

Cardiovascular mortality has decreased over the last 40 years in Western countries; however, patients with diabetes still have high mortality and show a two- to four-fold increased risk of cardiovascular events over those without diabetes [1]. This increased risk is generally attributed to the adverse effects of hyperglycaemia and oxidative stress, the two main factors that cause vascular endothelial cell damage and consequently diabetic vascular complications [2].

$\mathrm{Ca}^{2+}$ signalling is critical in regulating endothelial function. Many inflammatory mediators, such as thrombin, histamine and cytokines, increase intracellular $\mathrm{Ca}^{2+}$ concentration $\left(\left[\mathrm{Ca}^{2+}\right]_{i}\right)$ through activation of $G$ protein-coupled receptors or receptor tyrosine kinases [3, 4]. Signalling through these receptors leads to the generation of inositol 1, 4, 5-trisphosphate $\left(\mathrm{IP}_{3}\right), \mathrm{IP}_{3}$ receptor activation, depletion of $\mathrm{Ca}^{2+}$ from intracellular stores, and the opening of $\mathrm{Ca}^{2+}$-permeable channels in the plasma membrane, i.e., store-operated channels (SOCs) or $\mathrm{Ca}^{2+}$ release-activated channels (CRACs) [4]. ORAI and transient receptor potential (TRP) channel proteins have been proposed as the molecular fingerprints for SOCs. ORAIs mediate the highly $\mathrm{Ca}^{2+}$-selective and inward rectifying $\mathrm{Ca}^{2+}$ release-activated $\mathrm{Ca}^{2+}$ current $\left(I_{\mathrm{CRAC}}\right)$ [5, 6], while TRPCs mediate the non-selective $\mathrm{Ca}^{2+}$-permeable cationic current with outward rectification [7, 8]. These channels are associated with the $\mathrm{Ca}^{2+}$ sensor protein STIM1 (stromal interaction molecule 1) in the endoplasmic reticulum (ER), which senses the depleted $\mathrm{Ca}^{2+}$ store and couples to the SOCs in the plasma membrane through subplasmalemmal translocation and clustering [9-13].

ORAI and TRPC channels play important roles in the regulation of endothelial function including permeability, proliferation, migration, secretion, apoptosis and angiogenesis [1416]. Changes in the expression of TRPC channels have been reported in the context of diabetes. For example, TRPC1 and TRPC6 were shown to be upregulated in the smooth muscle of tail artery from Goto-Kakizaki type 2 diabetic rats [17], but downregulated in diabetic human saphenous vein [18]. In human umbilical vein endothelial cells (HUVECs), increased SOC activity was suggested to mediate high glucose (HG)-induced apoptosis [19]. Store-operated $\mathrm{Ca}^{2+}$-entry was impaired due to decreased STIM1 expression in the coronary artery endothelial cells isolated from streptozotocin-induced diabetic mice [20]; however, an opposite effect was reported in human glomerular mesangial cells [21]. The effect of HG on ORAI channels is still unknown. Here, we investigated the expression of ORAIs and STIMs 
and their regulatory mechanisms under $\mathrm{HG}$ condition and hyperglycaemic state using in vitro cell models and tissue samples from diabetic mice and patients.

\section{Materials and methods}

\section{Animals and human blood vessel samples}

Akita type 1 diabetic mice (C57BL/6-Ins $2^{\text {Akita } / J) ~ w e r e ~ o b t a i n e d ~ f r o m ~ t h e ~ J a c k s o n ~ l a b o r a t o r i e s ~}$ and bred at Lund University. Heterozygous Akita and control wild-type adult mice (mix genders at $12 \pm 1$ weeks old) were treated with daily intraperitoneal (i.p.) injections of NFAT blocker A-285222 (Abbott Laboratories, Abbott Park, IL) at a dose of $0.29 \mathrm{mg}$ per kg body weight or vehicle (saline) for four weeks. At the end of the study, mice were anaesthetized by i.p. injection of ketamine hydrochloride and xylazine $(2.5 \mathrm{mg}$ and $7.5 \mathrm{mg} / 100 \mathrm{~g}$ body weight, respectively) and euthanized by exsanguination through cardiac puncture, after which the abdominal aortae were dissected out, cleaned and frozen in liquid nitrogen for future mRNA analysis. Also, adult C57BL/6 mice (12-15 weeks old) were used as streptozocin (STZ)induced type 1 diabetic model by i.p. injections of STZ (Sigma-Aldrich, Stockholm, Sweden; $60 \mathrm{mg} / \mathrm{kg}$ body weight, $\mathrm{pH} \mathrm{4.5)}$ once a day for 5 days, as previously described, and the control mice received vehicle (citrate buffer) instead [22]. The animal study conforms to the Guide for the Care and Use of Laboratory Animals published by the Directive 2010/63/EU of the European Parliament. The use of animal for research was approved by the Malmö/Lund Animal Care and Use Committee.

Human aorta, saphenous vein, left internal mammary artery (LIMA) and renal artery samples were obtained from patients undergoing cardiac surgery or nephrectomy in East Yorkshire NHS Trust Hospitals. The project was approved by the local ethics committee and patients gave informed consent in accordance with the Declaration of Helsinki. Samples were collected in cold Hank's balanced salt solution (Invitrogen, UK) and transported into the laboratory immediately for experiments.

\section{Cell culture}

Primary human aortic endothelial cells (HAECs) were purchased from PromoCell (Heidelberg, Germany). Endothelial cells EA.hy926, a permanent cell line derived from HUVECs, were purchased from American Type Culture Collection (ATCC) (Middlesex, UK). Endothelial cells were cultured in endothelial cell medium (PromoCell, Germany) supplemented with $2 \%$ fetal calf serum (FCS), $0.1 \mathrm{ng} / \mathrm{ml}$ recombinant human epidermal 
growth factor, and $1 \mathrm{ng} / \mathrm{ml}$ basic fibroblast growth factor. Cells were maintained at $37^{\circ} \mathrm{C}$ under 95\% air and 5\% CO 2 . HEK293 T-REx cells were grown in DMEM-F12 medium (Invitrogen, UK) containing 10\% FCS, 100 units/ml penicillin and $100 \mu \mathrm{g} / \mathrm{ml}$ streptomycin. Cells were seeded on coverslips prior to experiments. Smooth muscle cells isolated from human saphenous vein and rat aorta were cultured [7] and used at passages 2-3.

\section{Cloning and transfection}

The full length of human ORAI1, ORAI2 and ORAI3 cDNAs were amplified from HAECs by RT-PCR and cloned into a tetracycline-regulatory vector pcDNA4/TO as we reported [13]. The sequences are $100 \%$ identical to the GenBank sequences with accession numbers NM_032790, NM_001126340 and NM_152288. The plasmid ORAI1 and ORAI2 cDNAs tagged with mCherry (monomeric cherry red fluorescence) and ORAI3 tagged with mCFP (monomeric cyan fluorescent protein) were transfected into HEK-293 T-REx cells using Lipofectamine 2000 (Invitrogen, Paisley, UK). For electrophysiological experiments, the tetracycline-inducible ORAI1-3 cells were cotransfected with STIM1 tagged with enhanced yellow fluorescent protein (STIM1-EYFP). Gene expression was induced by $1 \mu \mathrm{g} / \mathrm{ml}$ tetracycline for $24 \mathrm{~h}$ before recordings. For the study on NFAT signalling, the endothelial cells EA.hy926 were transfected with NFATc3 siRNA (Santa Cruz Biotech, Texas, USA) and reporter gene EYFP using Lipofectamine 2000 with similar procedures we described previously [23].

\section{Real-time RT-PCR}

Total RNA was extracted from cultured cells or tissues using NucleoSpin RNA II kit (Macherey-Nagel, Düren, Germany), and reverse transcribed with the moloney murine leukaemia virus (M-MLV) reverse transcriptase using random primers (Promega, UK). For mouse abdominal aorta samples, total RNA was isolated using TriReagent (Sigma-Aldrich, Poole, UK). Quantitative RT-PCR was performed using StepOne ${ }^{\mathrm{TM}}$ real-time PCR System (Applied Biosystems, UK). The primers were designed across introns and the sequences are given in Supplementary Table 1. Each reaction contained $5 \mu \mathrm{l} \mathrm{SYBR®} \mathrm{Green} \mathrm{PCR} \mathrm{Master}$ Mix (Applied Biosystems, UK), $0.5 \mu \mathrm{l}$ of $10 \mu \mathrm{M}$ forward primer, $1 \mu \mathrm{l}$ of $10 \mu \mathrm{M}$ reverse primer, $1 \mu \mathrm{cDNA}$ and $2.5 \mu \mathrm{l} \mathrm{H}_{2} \mathrm{O}$. The PCR cycle consisted of an initial denaturation step of $94^{\circ} \mathrm{C}$ for 5 minutes followed by 55 repeated cycles of $94^{\circ} \mathrm{C}$ for 30 seconds, $54^{\circ} \mathrm{C}$ for 45 seconds, and $72^{\circ} \mathrm{C}$ for 45 seconds, with a final cycle of extension at $72^{\circ} \mathrm{C}$ for 10 minutes. The melting curve analysis was performed for quality control. $\beta$-actin was used as house-keeping 
gene control for quantification. PCR products were also confirmed by $2 \%$ agarose gel electrophoresis or direct sequencing.

\section{Western blotting}

Cells were lysed in RIPA buffer (Sigma-Aldrich, Poole, UK) and proteins were separated on 10\% SDS-PAGE gel before transferring onto nitrocellulose membrane [24]. The blot was incubated with rabbit polyclonal anti-human ORAI1, ORAI2, STIM1, STIM2 (Alomone Labs, Jerusalem, Israel) and ORAI3 (ProSci Incorporated, Poway, CA, USA) antibodies overnight at $4{ }^{\circ} \mathrm{C}$, washed with phosphate buffered saline (PBS) and then incubated with goat anti-rabbit IgG-HRP (1:2000 dilution) (Sigma). The rabbit anti- $\beta$-actin (1:400 dilution) (Santa Cruz Biotech, USA) was used as an internal standard for protein quantification. Visualization was carried out using ECLplus detection reagents (GE Healthcare, UK) with Xray films or photographed by a gel documentation system (UVP, Cambridge, UK). The band density was analysed using ImageJ software (NIH, USA).

\section{Immunohistochemistry and immunofluorescence}

Paraffin-embedded human LIMA tissue sections with a thickness of $5 \mu \mathrm{m}$ were stained with rabbit anti-ORAI1, anti-ORAI2 and anti-ORAI3 antibodies using VECTASTAIN ABC kit (Vector Labs, Peterborough, UK). All sections underwent deparaffinisation, endogenous peroxidase blocking, and the blocking in non-specific serum to ensure the staining was specific. ORAI1, ORAI2 and ORAI3 primary antibodies at 1:250 dilutions were used and the tissue sections were incubated at $4^{\circ} \mathrm{C}$ overnight followed by biotinylated anti-mouse/rabbit immunoglobulins at 1:1000 for $20 \mathrm{~min}$. Incubations with antigen pre-absorbed antibodies or without primary antibody were used as negative controls.

Frozen tissue sections of kidney containing small arteries were fixed with $4 \%$ paraformaldehyde and permeabilised by incubation in $-20^{\circ} \mathrm{C}$ methanol for 1 minute and $0.1 \%$ Triton X-100 in PBS for 2 hours at room temperature. Sections were incubated in $1 \%$ bovine serum albumin (BSA) to block non-specific binding and then incubated in the appropriate ORAI primary antibodies at 1:200-500 dilutions in PBS with $1 \%$ BSA at $4{ }^{\circ} \mathrm{C}$ overnight. Tissue sections were washed three times with PBS then incubated in the sheep anti-rabbit IgG conjugated with FITC (Sigma) at a dilution of 1:160 for 2 hours at room temperature. Sections were double stained with $\mathrm{Cy} 3$ conjugated monoclonal anti- $\alpha$-smooth muscle actin ( $\alpha$-SMA) at a dilution of 1:200 (Sigma). After three washes with PBS, coverslips were 
mounted using Vectashield mounting medium (Vector Laboratories). The staining was photographed using a fluorescent microscope with acquisition software.

\section{Electrophysiology, $\mathrm{Ca}^{2+}$ dye and live cell fluorescent imaging}

Whole-cell patch-clamp recordings were performed on the HEK293 T-REx cells overexpressing mCherry-ORAIs and STIM1-EYFP as the procedures described [25]. The standard bath solution contained $(\mathrm{mM}): 130 \mathrm{NaCl}, 5 \mathrm{KCl}, 8$ D-glucose, 10 HEPES, 1.2 $\mathrm{MgCl}_{2}$ and $1.5 \mathrm{CaCl}_{2}$. The $\mathrm{pH}$ was adjusted to 7.4 using $\mathrm{NaOH}$. The pipette solution contained (mM): 145 Cs-methanesulfonate, 10 BAPTA, $10 \mathrm{HEPES}, 8 \mathrm{MgCl}_{2}$, and the $\mathrm{pH}$ was titrated to 7.2 with $\mathrm{CsOH}$. The recording chamber had a volume of $150 \mu \mathrm{l}$ and was perfused at a rate of about $2 \mathrm{ml} / \mathrm{min}$. The glass pipette with 3-5 $\mathrm{M} \Omega$ resistance was used and a 1-s voltage ramp from $-100 \mathrm{mV}$ to $+100 \mathrm{mV}$ was applied. The electrical signal was acquired by pClamp10. Experiments were performed at room temperature $\left(22-26^{\circ} \mathrm{C}\right)$.

For $\mathrm{Ca}^{2+}$ imaging experiments, the EA.hy926 cells on coverslips were incubated with $1 \mu \mathrm{M}$ Fura-PE3/AM for $30 \mathrm{~min}$ at $37^{\circ} \mathrm{C}$ in standard bath solution and washed with $\mathrm{Ca}^{2+}$ free standard bath solution ( $\mathrm{Ca}^{2+}$ was replaced by $0.4 \mathrm{mmol} / \mathrm{L}$ EGTA) for $2 \mathrm{~min}$ before recording. The ratio $\left(\mathrm{F}_{340} / \mathrm{F}_{380}\right)$ of $\mathrm{Ca}^{2+}$ dye fluorescence was measured by a Nikon Ti-E system with NIS-Element $\mathrm{Ca}^{2+}$ imaging software (Nikon, Tokyo, Japan). For live cell fluorescent imaging, the stable cells transfected with STIM1-EYFP were used and the movement of STIM1-EYFP fluorescence were monitored using the Nikon Ti-E imaging system [13].

\section{Statistics}

All values are expressed as mean \pm SEM. Unpaired student's $t$ test and ANOVA with Dunnett's post-hoc analysis were used for comparison of 2 groups and more than 2 groups, respectively. The significance is indicated if $P<0.05$.

\section{Results}

\section{STIM and ORAI expression and regulation by HG}

The mRNAs of ORAI1-3 and STIM1-2 were detected by RT-PCR in fresh human blood vessels including aorta, LIMA, saphenous vein, as well as in human endothelial cells (ECs) and smooth muscle cells (SMCs) (Fig. 1A). ORAI and STIM proteins were also detected by Western blotting in HAECs (Fig. 1B), EA.hy926 and human LIMA (Supplementary Fig. 1). Positive immunostaining was seen both in the endothelium and smooth muscle layer in 
human LIMA (Fig. 1C) and small renal arteries (Fig. 1D), suggesting that ORAI and STIM are ubiquitously expressed in vascular endothelial and smooth muscle cells in various vascular beds.

Using real-time PCR, we found that the mRNA levels of ORAI1, 2, 3 and STIM1, 2 were significantly upregulated in the endothelial cells incubated with $\mathrm{HG}(25 \mathrm{mM})$ for $72 \mathrm{~h}$ (Fig. 1E). Protein levels of ORAI and STIM isoforms in the HG-treated cells were also increased (Fig. 1F). Similar upregulation by HG was observed in primary cultured rat aortic smooth muscle cells (Supplementary Fig. 2A).

The findings on in vitro cell models were further confirmed using arteries form type 1 diabetic Akita mice. These mice have a mutation in the insulin 2 gene (Ins2 ${ }^{\text {Akita }}$ ) and are characterized by hyperglycaemia without significant weight loss (see Supplementary Table 2). Expression of ORAI1-3 and STIM1-2 mRNAs was significantly increased in the abdominal aorta of Akita mice when compared to samples from wild-type controls (Fig. 2A). Same results were observed in abdominal aortae from STZ-diabetic mice when compared to arteries from control non-diabetic mice (Supplementary Fig. 3). We also examined the expression in diabetic human aorta samples from type 2 diabetic patients (male; $57 \pm 2.8$ years of age) undergoing cardiac bypass surgery. Samples from age- and body mass index (BMI; $30 \pm 1.6 \mathrm{~kg} / \mathrm{m}^{2}$ vs $\left.30 \pm 2.0 \mathrm{~kg} / \mathrm{m}^{2}, P>0.05\right)$-matched male patients without diabetes were used as control. Expression of ORAI1, ORAI2, STIM1 and STIM2 mRNAs was significantly higher in the aortae obtained from diabetic patients (Fig. 2B). These data suggest that the ORAIs and STIMs are upregulated in diabetes.

\section{Upregulation of ORAI and STIM is mediated by $\mathrm{Ca}^{2+}$-calcineurin-NFATc signalling}

The $\mathrm{Ca}^{2+}$-calcineurin-NFAT signalling pathway was examined using in vitro cell models and in vivo Akita mouse model. HG-induced upregulation of ORAIs and STIMs was prevented by incubation with the calcineurin inhibitor cyclosporin A (CsA, $200 \mathrm{nM}$ ) for $48 \mathrm{~h}$ in vascular endothelial cells (Fig. 3A) and in smooth muscle cells (Supplementary Fig. 2B). Application of CsA alone also reduced the expression of ORAI1-3 and STIM1-2 in endothelial cells, suggesting that the basal activity of calcineurin signalling could be essential for maintaining constitutive ORAI and STIM gene expression (Fig. 3A). NFATc3 has previously been shown to be activated by hyperglycaemia in vascular smooth muscle through a mechanism involving intracellular $\mathrm{Ca}^{2+}$ increase via $\mathrm{P} 2 \mathrm{Y}$ receptors and subsequent activation of calcineurin, combined with the inhibition of GSK-3 $\beta$ and JNK that can reduce NFATc3 nuclear export 
$[22,26]$. Therefore the role of this particular isoform in HG-induced gene expression was also examined in the endothelial cells using RNA interference. The endogenous NFATc3 expression was nearly abolished after transfection with specific NFATc3 siRNA (Fig. 3B). HG significantly increased the expression of NFATc3 (Fig. 3C). Knockdown of NFATc3 by siRNA prevented the HG-induced upregulation of ORAI1-3 and STIM1-2 (Fig. 3D). To further confirm the regulation through calcineurin-NFATc pathway in vivo, Akita and control non-diabetic mice were treated with daily i.p. injections of the NFAT blocker A-285222 (0.29 $\mathrm{mg} / \mathrm{kg}$ body weight) or vehicle (saline) for 4 weeks and then abdominal aortae were harvested for real-time PCR. The enhanced expression of ORAI and STIM in Akita mice was significantly decreased by treatment with A-285222 (Fig. 3E). These data suggest that the upregulation of ORAI and STIM gene expression by HG is mediated by the $\mathrm{Ca}^{2+}$-calcineurinNFATc signalling pathway.

\section{HG enhanced $\mathrm{Ca}^{2+}$ release and influx in vascular endothelial cells}

To examine SOC activity under high glucose conditions, $\mathrm{Ca}^{2+}$ influx was monitored using Fura-PE3/AM in vascular endothelial cells EA.hy926. Acute application of HG (25 mM) did not change $\mathrm{Ca}^{2+}$ influx in the cells pretreated with or without thapsigargin (TG, $\left.1 \mu \mathrm{M}\right)$ (Fig. 4A-C ). In contrast, incubation of the cells with $25 \mathrm{mM}$ glucose for $72 \mathrm{~h}$ resulted in enhanced store-operated $\mathrm{Ca}^{2+}$ influx without affecting basal $\mathrm{Ca}^{2+}$ level (Fig. 4D-E). The effects of $\mathrm{HG}$ on non-store-depleted $\mathrm{Ca}^{2+}$ influx, $\mathrm{Ca}^{2+}$ release and store-depleted $\mathrm{Ca}^{2+}$ influx after active ER $\mathrm{Ca}^{2+}$ store depletion were also observed using trypsin, an activator of $\mathrm{G}$ protein-coupled receptor. The non-store-depleted $\mathrm{Ca}^{2+}$ influx was greater in the cells incubated with HG. The $\mathrm{Ca}^{2+}$ release signal and $\mathrm{Ca}^{2+}$ influx induced by trypsin $(0.1 \mathrm{nM})$ were also significantly higher in the HG-treated group than those in the control group (Fig. 4F-G). These data suggest that HG has no acute effect on $\mathrm{Ca}^{2+}$ influx, but it enhances store-operated $\mathrm{Ca}^{2+}$ influx, non-storeoperated $\mathrm{Ca}^{2+}$ influx and $\mathrm{Ca}^{2+}$ release in the cells exposed to $\mathrm{HG}$ chronically.

\section{Direct effects of HG on ORAI channel activity and STIM1 movement}

To determine whether HG affects ORAI channel opening, whole-cell patch clamp was performed in the inducible HEK293 T-REx cells coexpressing STIM1-EYFP and mCherrytagged ORAI1 or ORAI2, or mCFP-tagged ORAI3. Perfusion with $25 \mathrm{mM}$ glucose did not change the TG-induced ORAI1 and ORAI2 currents and the 2-APB-induced ORAI3 current; however, DES significantly inhibited the currents of all three ORAI isoforms (Fig. 5A-D). 
STIM1 subplasmalemmal translocation and clustering are essential steps for triggering ORAI channel opening, which could serve as targets for SOC regulators [10, 13], we therefore examined if HG affects STIM1 translocation and clustering. In the HEK293 T-REx cells overexpressing STIM1-EYFP, the STIM1 subplasmalemmal translocation and puncta formation were evoked by TG (Fig. 5E), but acute perfusion with $\mathrm{HG}$ or chronic treatment by incubation with HG for $72 \mathrm{~h}$ did not cause STIM1 clustering or affect the TG-induced STIM1 movement (Fig. 5E-G). These data suggest that HG has no direct effects on ORAI channel activity and intracellular STIM1 movement.

\section{Discussion}

In this study, we have shown that store-operated $\mathrm{Ca}^{2+}$ entry in vascular endothelial cells and smooth muscle cells is enhanced by chronic treatment with HG. The enhancement is mediated by upregulation of ORAI1-3 and STIM1-2 expression, rather than by direct channel activation of ORAI1-3 or movement of STIM1 during store-operated channel activation. STIMs and ORAIs upregulation was also demonstrated in vivo using samples from type 2 diabetic patients and from type 1 diabetic animal models. Inhibition of calcineurin/NFAT signalling pathway, either via decreased activation by calcineurin or A-285222 or via decreased expression of NFATc3 via siRNA, prevents the HG-induced STIM and ORAI gene upregulation. These findings suggest that the upregulation of store-operated channel molecules is responsible for the enhanced store-operated channel function seen in hyperglycaemia and diabetic conditions.

Previous studies have shown that $\mathrm{HG}$ affects intracellular $\mathrm{Ca}^{2+}$ level or $\mathrm{Ca}^{2+}$ homeostasis [2729]. The different responses between acute application and chronic treatment has been demonstrated, i.e., acute application of $\mathrm{HG}$ had less effect on $\mathrm{Ca}^{2+}$ influx, but chronic treatment by incubation with $\mathrm{HG}$ for 2-4 days significantly increased the $\mathrm{Ca}^{2+}$ influx in HUVECs [19], porcine aortic endothelial cells [30] and in EA.hy926 cells as shown in this study and others [31]; however, an opposite effect was reported in mouse coronary endothelial cells [20]. In vascular endothelial cells, chronic treatment with HG not only increases store-operated $\mathrm{Ca}^{2+}$ entry, but also increases the $\mathrm{Ca}^{2+}$ release and OAG-induced $\mathrm{Ca}^{2+}$ influx [32], which suggests other $\mathrm{Ca}^{2+}$-permeable channels may also be involved in the regulation of $\mathrm{Ca}^{2+}$ homeostasis in hyperglycaemia, such as the regulation of TRPC1, TRPC36, and TRPM6-7 in human monocytes, platelets and endothelial cells under diabetic 
conditions or hyperglycaemia [17, 18, 32-34]. In this study, we have not explored other channels, but focused on the store-operated components related to STIMs and ORAIs. The mechanism for HG-induced upregulation of store-operated channel genes is unclear, here we suggest that the $\mathrm{Ca}^{2+} /$ calcineurin signalling pathway is important for ORAI and STIM gene expression, because inhibition of calcineurin or NFAT with CsA or A-285222, respectively, or silencing of NFATc3 expression using siRNA prevents the HG-induced effect. In addition, NFATc3 was upregulated by HG as shown in this study, and increased activity and nuclear accumulation of NFATc3 were also observed in the diabetic mice with hyperglycaemia in vivo [22]. These data further demonstrate the role of $\mathrm{Ca}^{2+} /$ calcineurin/NFATc3 signalling pathway in the HG-induced gene regulation. Although cytosolic $\mathrm{Ca}^{2+}$ is essential for activating or maintaining the activity of $\mathrm{Ca}^{2+} /$ calcineurin/NFATc3 signalling, other mechanisms may also be involved in the gene regulation under hyperglycemic or diabetic conditions, such as mitochondrial stress signalling, intracellular $\mathrm{Ca}^{2+}$ dynamics, and some kinase activities. For example, GSK-3 $\beta$ and JNK can decrease NFATc3 nuclear export [26]. On the other hand, overproduction of reactive oxygen species (ROS) under high glucose or diabetic conditions could be another potential pathway for gene regulation, since $\mathrm{H}_{2} \mathrm{O}_{2}$ can directly activate the $I_{\text {CRAC }}$ current and other $\mathrm{Ca}^{2+}$-permeable channels $[23,35,36]$, increase cytosolic $\mathrm{Ca}^{2+}$ concentration and subsequently activate the downstream calcineurin/NFAT signaling. In addition, an oxidative stress mechanism has also been suggested for TRPC3 and TRPC6, since the membrane-permeable radical scavenger, tempol, prevented the effect of HG [34]. Therefore, oxidative stress could directly alter the $\mathrm{Ca}^{2+}$ homeostasis through nonstore-operated pathways, such as TRPM2, and thus alter the downstream $\mathrm{Ca}^{2+} /$ calcineurin signaling and gene transcription [37]. Although the evidence for the upregulation of ORAIs and STIMs in vascular endothelia cells and smooth muscle cells are evident, the response to $\mathrm{HG}$ for other $\mathrm{Ca}^{2+}$ channels in different cell types is still unclear, such as downregulation of TRPC6 and decreased receptor-operated $\mathrm{Ca}^{2+}$ influx found in diabetic mesangial cells [38, 39]. Recently, ORAI1/3 channels, but not ORAI2, could mediate arachidonic acid and leukotriene $\mathrm{C} 4$ regulated non-store-operated $\mathrm{Ca}^{2+}$ influx and current through interaction with plasma membrane STIM1[40], therefore, upregulation of ORAI1-3 and STIM1-2 could also be responsible for the enhanced non-store operated $\mathrm{Ca}^{2+}$ entry, particularly under the conditions of increased vascular or endothelial inflammatory response seen in diabetes and hyperglycemia. 
In conclusion, HG increases store-operated calcium entry by upregulation of ORAI and STIM in vitro and in vivo via the $\mathrm{Ca}^{2+} /$ calcineurin/NFAT pathway. The increased storeoperated channel activity or related gene expression is a potential critical step in the pathophysiology of diabetic vascular complications. Further elucidation of this $\mathrm{Ca}^{2+}$ signalling pathway may provide new potential therapeutic opportunities for the treatment of these vascular complications in patients with diabetes.

\section{Addendum}

N. Daskoulidou and S.Z. Xu designed the study. N. Daskoulidou, B. Zeng, H. Jiang and G.L. Chen performed the experiments. L.M. Berglund and O. Kotova and M.F. Gomez were responsible for diabetic mice models. S. Bhandari, J. Ayoola and S. Griffin collected clinical data and human tissue samples. S.Z. Xu, S.L. Atkin and M.F. Gomez and conceived the study. S.Z. Xu and N. Daskoulidou wrote the manuscript. All the authors critically reviewed the manuscript.

\section{Acknowledgements}

We thank Prof. AV Tepikin (University of Liverpool) for providing the STIM1-EYFP cDNA, Prof. DJ Beech for comments on the manuscript, and Dr. A Green (University of Hull) for technical help. This work was supported in part by British Heart Foundation and Leverhulme Trust (to S.Z.X), University PhD studentship (to N.D.), and China Scholarship Council (to B.Z.), and also by the Swedish Research Council (\#2011-3900), Swedish Heart and Lung foundation, Albert Påhlsson and Diabetes foundations, and Innovative Medicines Initiative Joint Undertaking [\#115006] comprising funds from the European Union's Seventh Framework Programme [FP7/2007-2013] (to M.F.G.).

\section{Conflict of Interests.}

The authors state that they have no conflict of interest.

\section{References}


1. Roger VL, Go AS, Lloyd-Jones DM, Benjamin EJ, Berry JD, Borden WB, Bravata DM, Dai S, Ford ES, Fox CS, et al (2012) Heart disease and stroke statistics--2012 update: a report from the American Heart Association. Circulation 125: e2-e220. DOI

CIR.0b013e31823ac046 [pii]

10.1161/CIR.0b013e31823ac046

2. Avogaro A, Albiero M, Menegazzo L, de Kreutzenberg S, Fadini GP (2011) Endothelial Dysfunction in Diabetes. Diabetes Care 34: S285-S290. DOI 10.2337/dc11-s239

3. Kiselyov K, Shin DM, Muallem S (2003) Signalling specificity in GPCR-dependent Ca2+ signalling. Cell Signal 15: 243-253. DOI S0898656802000748 [pii]

4. Parekh AB, Putney JW (2005) Store-Operated Calcium Channels. Physiological Reviews 85: 757-810. DOI 10.1152/physrev.00057.2003

5. Vig M, Peinelt C, Beck A, Koomoa DL, Rabah D, Koblan-Huberson M, Kraft S, Turner H, Fleig A, Penner R, et al (2006) CRACM1 Is a Plasma Membrane Protein Essential for Store-Operated Ca2+ Entry. Science: 1127883. DOI 10.1126/science.1127883

6. Yeromin AV, Zhang SL, Jiang W, Yu Y, Safrina O, Cahalan MD (2006) Molecular identification of the CRAC channel by altered ion selectivity in a mutant of Orai. Nature 443: 226-229. DOI

http://www.nature.com/nature/journal/v443/n7108/suppinfo/nature05108_S1.html

7. Xu SZ, Muraki K, Zeng F, Li J, Sukumar P, Shah S, Dedman AM, Flemming PK, McHugh D, Naylor J, et al (2006) A sphingosine-1-phosphate-activated calcium channel controlling vascular smooth muscle cell motility. Circ Res 98: 1381-1389. DOI

01.RES.0000225284.36490.a2 [pii]

\subsection{1/01.RES.0000225284.36490.a2}

8. Xu SZ, Boulay G, Flemming R, Beech DJ (2006) E3-targeted anti-TRPC5 antibody inhibits store-operated calcium entry in freshly isolated pial arterioles. Am J Physiol Heart Circ Physiol 291: H2653-2659. DOI 00495.2006 [pii]

10.1152/ajpheart.00495.2006

9. Hogan PG, Lewis RS, Rao A (2010) Molecular basis of calcium signaling in lymphocytes: STIM and ORAI. Annual Review of Immunology 28: 491-533

10. Zhang SL (2005) STIM1 is a Ca2+ sensor that activates CRAC channels and migrates from the $\mathrm{Ca} 2+$ store to the plasma membrane. Nature 437: 902-905

11. Lee KP, Yuan JP, So I, Worley PF, Muallem S (2010) STIM1-dependent and STIM1independent Function of Transient Receptor Potential Canonical (TRPC) Channels Tunes Their Store-operated Mode. The Journal of Biological Chemistry 285: 38666-38673. DOI 10.1074/jbc.M110.155036 
12. Pani B, Ong HL, Brazer SC, Liu X, Rauser K, Singh BB, Ambudkar IS (2009) Activation of TRPC1 by STIM1 in ER-PM microdomains involves release of the channel from its scaffold caveolin-1. Proceedings of the National Academy of Sciences USA 106: 20087-20092. DOI 0905002106 [pii]

10.1073/pnas.0905002106

13. Zeng B, Chen GL, Xu SZ (2012) Store-independent pathways for cytosolic STIM1 clustering in the regulation of store-operated $\mathrm{Ca}(2+)$ influx. Biochem Pharmacol 84: 10241035. DOI S0006-2952(12)00495-9 [pii]

10.1016/j.bcp.2012.07.013

14. Tiruppathi C, Ahmmed GU, Vogel SM, Malik AB (2006) Ca2+ signaling, TRP channels, and endothelial permeability. Microcirculation 13: 693-708. DOI N4K5PR3212721X87 [pii]

$10.1080 / 10739680600930347$

15. Abdullaev IF, Bisaillon JM, Potier M, Gonzalez JC, Motiani RK, Trebak M (2008) Stim1 and Orai1 Mediate CRAC Currents and Store-Operated Calcium Entry Important for Endothelial Cell Proliferation. Circ Res 103: 1289-1299. DOI 10.1161/01.res.0000338496.95579.56

16. Li J, Cubbon RM, Wilson LA, Amer MS, McKeown L, Hou B, Majeed Y, Tumova S, Seymour VAL, Taylor H, et al (2011) Orai1 and CRAC Channel dependence of VEGFactivated Ca2+ entry and endothelial tube formation. Circ Res 108: 1190-1198. DOI 10.1161/circresaha.111.243352

17. Mita M, Ito K, Taira K, Nakagawa J, Walsh MP, Shoji M (2010) Attenuation of storeoperated $\mathrm{Ca} 2+$ entry and enhanced expression of TRPC channels in caudal artery smooth muscle from Type 2 diabetic Goto-Kakizaki rats. Clin Exp Pharmacol Physiol 37: 670-678. DOI CEP5373 [pii]

\subsection{1/j.1440-1681.2010.05373.x}

18. Chung AW, Au Yeung K, Chum E, Okon EB, van Breemen C (2009) Diabetes modulates capacitative calcium entry and expression of transient receptor potential canonical channels in human saphenous vein. Eur J Pharmacol 613: 114-118. DOI S00142999(09)00342-2 [pii]

10.1016/j.ejphar.2009.04.029

19. Tamareille S, Mignen O, Capiod T, Rucker-Martin C, Feuvray D (2006) High glucose-induced apoptosis through store-operated calcium entry and calcineurin in human umbilical vein endothelial cells. Cell Calcium 39: 47-55. DOI S0143-4160(05)00181-8 [pii]

10.1016/j.ceca.2005.09.008 
20. Estrada IA, Donthamsetty R, Debski P, Zhou MH, Zhang SL, Yuan JX, Han W, Makino A (2012) STIM1 restores coronary endothelial function in type 1 diabetic mice. Circ Res 111: 1166-1175. DOI CIRCRESAHA.112.275743 [pii]

\subsection{1/CIRCRESAHA.112.275743}

21. Chaudhari S, Wu P, Wang Y, Ding Y, Yuan J, Begg M, Ma R (2014) High Glucose and Diabetes Enhanced Store-Operated Ca2+ Entry and Increased Expression of Its Siganling Proteins in Mesangial Cells. Am J Physiol Renal Physiol. DOI ajprenal.00463.2013 [pii]

10.1152/ajprenal.00463.2013

22. Nilsson-Berglund LM, Zetterqvist AV, Nilsson-Ohman J, Sigvardsson M, Gonzalez Bosc LV, Smith ML, Salehi A, Agardh E, Fredrikson GN, Agardh CD, et al (2010) Nuclear factor of activated $\mathrm{T}$ cells regulates osteopontin expression in arterial smooth muscle in response to diabetes-induced hyperglycemia. Arterioscler Thromb Vasc Biol 30: 218-224. DOI ATVBAHA.109.199299 [pii]

10.1161/ATVBAHA.109.199299

23. Xu SZ, Zhong W, Watson NM, Dickerson E, Wake JD, Lindow SW, Newton CJ, Atkin SL (2008) Fluvastatin reduces oxidative damage in human vascular endothelial cells by upregulating Bcl-2. J Thromb Haemost 6: 692-700. DOI JTH2913 [pii]

10.1111/j.1538-7836.2008.02913.x

24. Xu S-Z, Sukumar P, Zeng F, Li J, Jairaman A, English A, Naylor J, Ciurtin C, Majeed Y, Milligan CJ, et al (2008) TRPC channel activation by extracellular thioredoxin. Nature 451: 69-72

25. Xu SZ, Zeng B, Daskoulidou N, Chen GL, Atkin SL, Lukhele B (2012) Activation of TRPC cationic channels by mercurial compounds confers the cytotoxicity of mercury exposure. Toxicol Sci 125: 56-68. DOI kfr268 [pii]

10.1093/toxsci/kfr268

26. Nilsson LM, Nilsson-Ohman J, Zetterqvist AV, Gomez MF (2008) Nuclear factor of activated T-cells transcription factors in the vasculature: the good guys or the bad guys? Curr Opin Lipidol 19: 483-490. DOI 10.1097/MOL.0b013e32830dd545

00041433-200810000-00008 [pii]

27. Kimura C, Oike M, Ito Y (1998) Acute glucose overload abolishes Ca2+ oscillation in cultured endothelial cells from bovine aorta: a possible role of superoxide anion. Circ Res 82: 677-685

28. Kimura C, Oike M, Kashiwagi S, Ito Y (1998) Effects of acute glucose overload on histamine $\mathrm{H} 2$ receptor-mediated $\mathrm{Ca} 2+$ mobilization in bovine cerebral endothelial cells.

Diabetes 47: 104-112 
29. Pieper GM, Dondlinger LA (1998) Antioxidant pyrrolidine dithiocarbamate prevents defective bradykinin-stimulated calcium accumulation and nitric oxide activity following exposure of endothelial cells to elevated glucose concentration. Diabetologia 41: 806-812. DOI 10.1007/s001250050991

30. Graier WF, Wascher TC, Lackner L, Toplak H, Krejs GJ, Kukovetz WR (1993) Exposure to elevated D-glucose concentrations modulates vascular endothelial cell vasodilatory response. Diabetes 42: 1497-1505

31. Paltauf-Doburzynska J, Malli R, Graier WF (2004) Hyperglycemic conditions affect shape and $\mathrm{Ca} 2+$ homeostasis of mitochondria in endothelial cells. J Cardiovasc Pharmacol 44: 423-436. DOI 00005344-200410000-00003 [pii]

32. Liu D, Maier A, Scholze A, Rauch U, Boltzen U, Zhao Z, Zhu Z, Tepel M (2008) High glucose enhances transient receptor potential channel canonical type 6-dependent calcium influx in human platelets via phosphatidylinositol 3-kinase-dependent pathway. Arterioscler Thromb Vasc Biol 28: 746-751. DOI ATVBAHA.108.162222 [pii]

10.1161/ATVBAHA.108.162222

33. Bishara NB, Ding H (2010) Glucose enhances expression of TRPC1 and calcium entry in endothelial cells. Am J Physiol Heart Circ Physiol 298: H171-178. DOI 00699.2009 [pii]

10.1152/ajpheart.00699.2009

34. Wuensch T, Thilo F, Krueger K, Scholze A, Ristow M, Tepel M (2010) High glucose-induced oxidative stress increases transient receptor potential channel expression in human monocytes. Diabetes 59: 844-849. DOI db09-1100 [pii]

$10.2337 / \mathrm{db} 09-1100$

35. Chen GL, Zeng B, Eastmond S, Elsenussi SE, Boa AN, Xu SZ (2012)

Pharmacological comparison of novel synthetic fenamate analogues with econazole and 2APB on the inhibition of TRPM2 channels. Br J Pharmacol 167: 1232-1243. DOI 10.1111/j.1476-5381.2012.02058.x

36. Grupe M, Myers G, Penner R, Fleig A (2010) Activation of store-operated I(CRAC) by hydrogen peroxide. Cell Calcium 48: 1-9. DOI S0143-4160(10)00085-0 [pii]

10.1016/j.ceca.2010.05.005

37. Graier WF, Simecek S, Hoebel BG, Wascher TC, Dittrich P, Kostner GM (1997) Antioxidants prevent high-D-glucose-enhanced endothelial Ca2+/cGMP response by scavenging superoxide anions. Eur J Pharmacol 322: 113-122. DOI S0014-2999(96)00989-2 [pii]

38. Graham S, Ding M, Sours-Brothers S, Yorio T, Ma JX, Ma R (2007) Downregulation of TRPC6 protein expression by high glucose, a possible mechanism for the impaired Ca2+ 
signaling in glomerular mesangial cells in diabetes. Am J Physiol Renal Physiol 293: F13811390. DOI 00185.2007 [pii]

10.1152/ajprenal.00185.2007

39. Nutt LK, O'Neil RG (2000) Effect of elevated glucose on endothelin-induced storeoperated and non-store-operated calcium influx in renal mesangial cells. J Am Soc Nephrol 11: $1225-1235$

40. Zhang X, Zhang W, Gonzalez-Cobos JC, Jardin I, Romanin C, Matrougui K, Trebak M (2014) Complex role of STIM1 in the activation of store-independent Orai1/3 channels. J Gen Physiol 143: 345-359. DOI jgp.201311084 [pii]

10.1085/jgp.201311084 
Figure 1. ORAI and STIM expression and regulation by HG. A, The mRNAs of ORAI1 (238bp), ORAI2 (210bp), ORAI3 (176bp), STIM1 (183bp) and STIM2 (202bp) were detected by RT-PCR using the primers across introns (Supplementary Table 1) in human left internal mammalian artery (LIMA), aorta, human saphenous vein (HSV), human aortic endothelial cells (HAECs), endothelial cell line EA.hy926, and smooth muscle cells (SMC) isolated from HSV. The $\beta$-actin (211bp) was used as positive control and the reaction without reverse transcriptase (no RT) was used as a negative control. B, ORAI and STIM proteins were detected in HAECs by western blotting with the protein band size for ORAI1 (31 kDa), ORAI2 (29 kDa), ORAI3 (31 kDa), STIM1 (77 kDa) and STIM2 (94 kDa). C, Immunostaining of paraffin-embedded sections of LIMA using Vectorshield ABC kit. Positive staining is shown as brown colour. Scale bar is $100 \mu \mathrm{m}$. D, Dual fluorescent staining of frozen sections of human renal arteries with anti-smooth muscle alpha actin ( $\alpha$-SMA, red) and anti-ORAI1-3 antibodies (green). Scale bar is $25 \mu \mathrm{m}$. E, The mRNA of ORAIs and STIMs detected by real-time PCR in vascular endothelial cells EA.hy926 after incubation with high glucose (HG, $25 \mathrm{mM})$ for $72 \mathrm{~h}$. RT-PCR reactions were performed for each sample ( $n=3$ for each group with triplicate PCR reactions), and $\beta$-actin was used as control for relative quantification. F, ORAI and STIM proteins detected by Western blotting in EA.hy926 cells. Mean \pm SEM data were obtained from 3 independent experiments. ${ }^{*} P<0.05$, $* * P<0.01, * * * P<0.001$.

Figure 2. ORAI and STIM expression in Akita mice and diabetic patients A, ORAI and STIM expression in Akita type 1 diabetic mice ( $n=6$ mice). The wild-type mice were set as control group. B, The mRNA levels of ORAIs and STIMs detected by real-time PCR in the aorta samples from type 2 diabetic patients $(n=4$ paired patients). Triplicate RT-PCR reactions were performed for each sample.

Figure 3. Regulation of ORAI and STIM expression by $\mathrm{Ca}^{2+}$-calcineurin signalling. A, The mRNA level quantified by real-time PCR in EA.hy926 cells after treatment with high glucose $(25 \mathrm{mM})$, mannitol $(19.5 \mathrm{mM})$ plus $5.5 \mathrm{mM}$ glucose as equal osmolarity control (control), cyclosporin A (CsA, $200 \mathrm{nM})$, and high glucose plus CsA for $48 \mathrm{~h}(n=3)$. B, Agarose gel showing NFATc3 PCR band in the non-transfected control EA.hy926 cells (lane 1-3) and the NFATc3-siRNA transfected cells (lane 4-6). The mean \pm SEM data was showed 
below $(n=6)$. C, The NFATc3 mRNA detected by real-time PCR after siRNA transfection and incubation with $\mathrm{HG}(25 \mathrm{mM})$ or mannitol $(19.5 \mathrm{mM})$ plus $5.5 \mathrm{mM}$ glucose as equal osmolarity control group for $48 \mathrm{~h}(n=6)$. D, Relative mRNA levels of STIMs and ORAIs in mannitol control (19.5 mM mannitol + 5.5 mM glucose), high glucose ( $\mathrm{HG}, 25 \mathrm{mM})$, and HG in cells transfected with NFATc3 siRNA $(\mathrm{HG}+\operatorname{siNFATc} 3) . N=3$ for each group with triplicate PCR reactions. All the three groups were transfected with pEGFP vector with green fluorescence as reporter gene to see the transfection efficiency. E, Real-time PCR detection of ORAI and STIM in the aortae after injection with A-285222 $(n=7$ for Akita group and 8 for wild-type) or vehicle ( $n=6$ for Akita group and 8 for wild-type). Triplicate reactions were set for each sample and $\beta$-actin was used for quantification. $* * P<0.01, * * * P<0.001$ (HG vs mannitol control). \#: $P<0.001$ (for comparisons $v$ s $\mathrm{HG}$ or hyperglycaemia).

Figure 4. $\mathrm{Ca}^{2+}$ influx regulated by high glucose in human vascular endothelial cells. A, Vascular endothelial cells EA.hy926 were loaded with Fura-PE3/AM and pretreated with 1 $\mu \mathrm{M}$ thapsigargin (+TG) for $30 \mathrm{~min}$. The fluorescence at a ratio of $\mathrm{F}_{340 / 380}$ was monitored before and after perfusion with high glucose $(25 \mathrm{mM})(n=17$ cells $)$. B, Acute application of mannitol $(25 \mathrm{mM})$ on $\mathrm{Ca}^{2+}$ influx in the store-depleted cells with $\mathrm{TG}$ ( $n=16$ cells). C, Acute application of high glucose $(25 \mathrm{mM})$ on $\mathrm{Ca}^{2+}$ influx in the cells without TG pretreatment (non-TG, $n=15$ cells). D, Store-operated $\mathrm{Ca}^{2+}$ influx in the endothelial cells after incubation with or without high glucose for $72 \mathrm{~h}$. The $\mathrm{ER} \mathrm{Ca}^{2+}$ store was depleted by preincubation with $1 \mu \mathrm{M}$ TG for $30 \mathrm{~min}$. E, Mean \pm SEM data showed the ratio measured in $\mathrm{Ca}^{2+}$ free and 1.5 $\mathrm{mM} \mathrm{Ca}{ }^{2+}$ solutions in the groups with $(n=52)$ or without $(n=49)$ chronic $(72 \mathrm{~h})$ incubation with high glucose as shown in (D). F, After $72 \mathrm{~h}$ incubation with or without high glucose, the $\mathrm{Ca}^{2+}$ influx was measured after admission of $\mathrm{Ca}^{2+}$, trypsin, and readmission of $\mathrm{Ca}^{2+}$. G, Mean \pm SEM data for the $\mathrm{Ca}^{2+}$ influx, $\mathrm{Ca}^{2+}$ release and $\mathrm{Ca}^{2+}$ reentry in the high glucose-treated $(n=$ $57)$ and untreated $(n=53)$ cells. $* P<0.05, * * P<0.01, * * * P<0.001$

\section{Figure 5. Effects of high glucose on ORAI channel activity and STIM1 movement.}

Whole-cell current was recorded in the inducible HEK293 T-REx cells co-overexpressing STIM1-EYFP and ORAI1-2 tagged with mCherry (red fluorescence), or ORAI3 tagged with mCFP (pseudo-red colour) and in the non-transfected cells. A, ORAI1. B, ORAI2. C, ORAI3. D, Non-transfected cell as control. The ORAI1 and ORAI2 channels were activated by $1 \mu \mathrm{M}$ thapsigargin in the bath solution and ORAI3 channel was activated by $100 \mu \mathrm{M} 2$-APB in the 
bath solution. Representative subtracted $I / V$ curves and time-courses are presented. Bar charts present the averaged data showing the effect of high glucose (HG, $25 \mathrm{mM}$ ) and diethylstilbestrol (DES, $1 \mu \mathrm{M}$ ) on the channel activity ( $n=12$ for each group). E, STIM1 movement induced by TG and the effect of HG. Scale bar is $10 \mu \mathrm{m}$. F-G, Fluorescent intensity of STIM1-EYFP in the plasma membrane and the average STIM1 cluster number in the cells $(n=15$ cells), $* * * P<0.001$. 
A

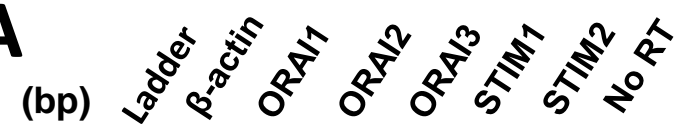
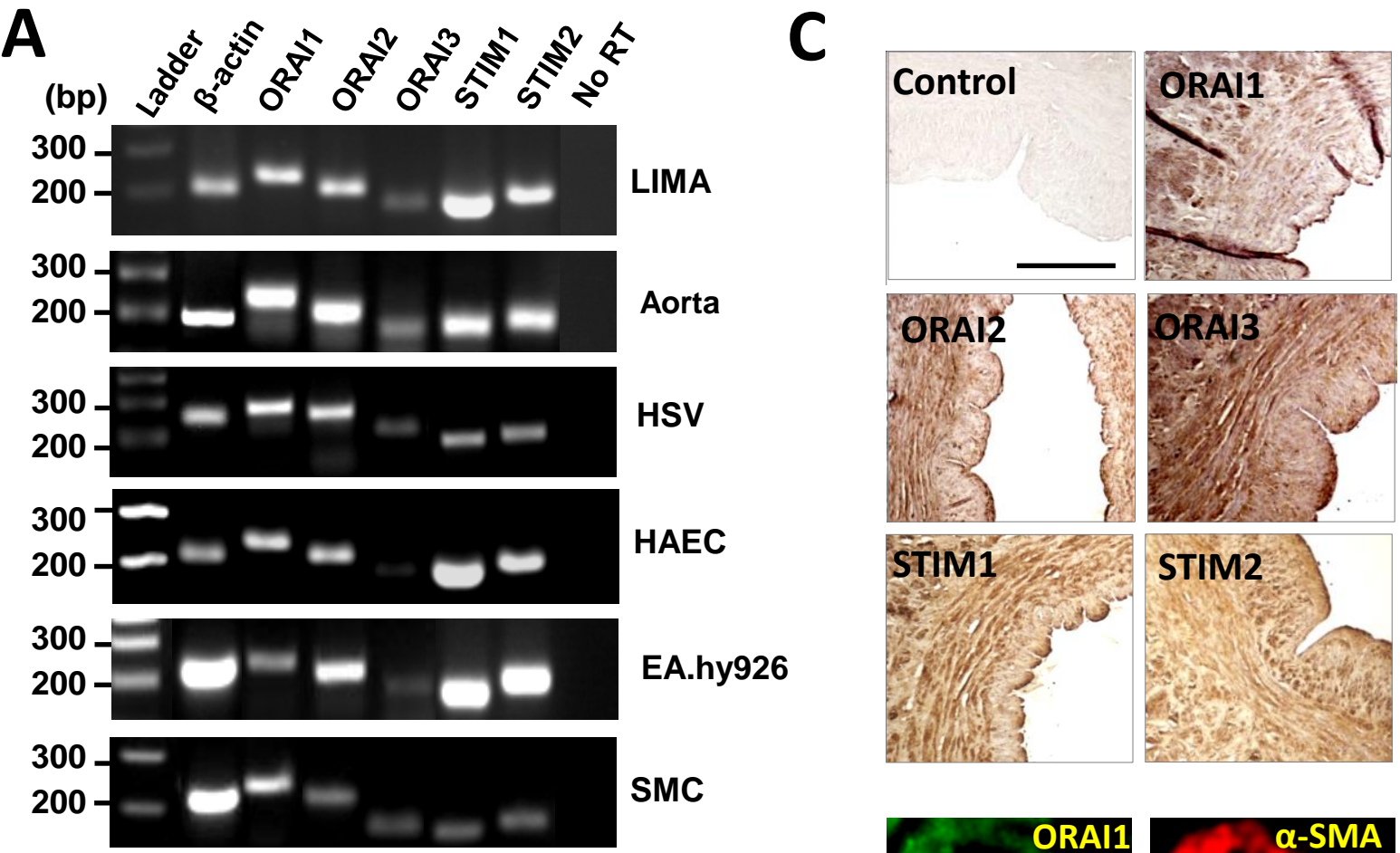

SMC

B
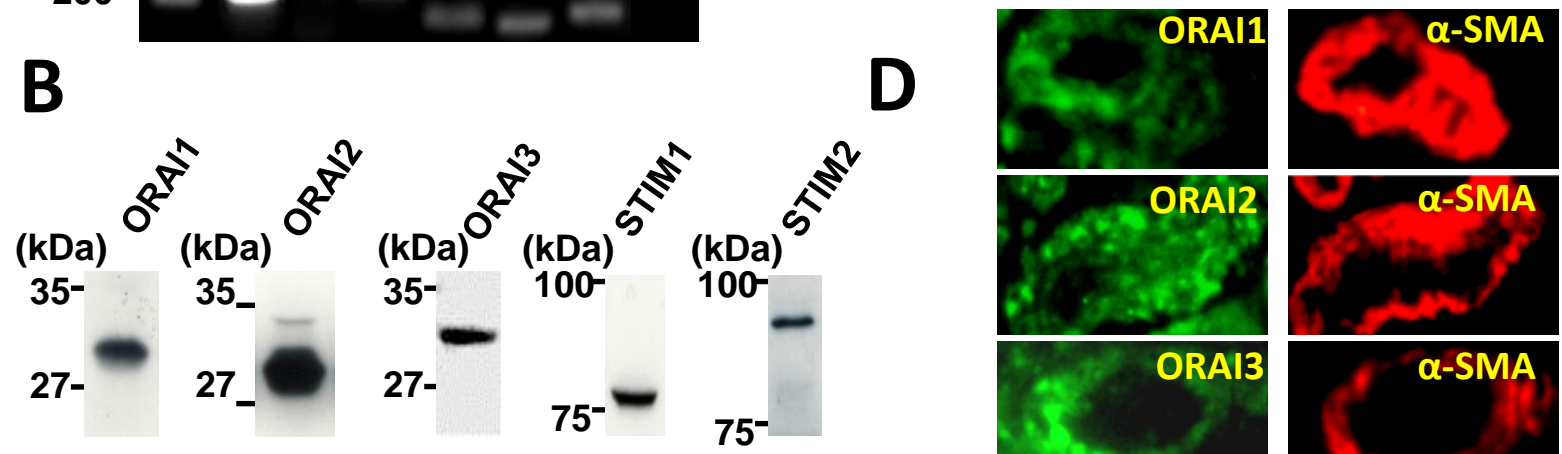

ORAI3
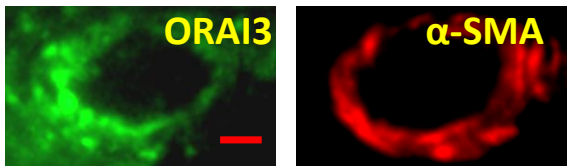

E

E
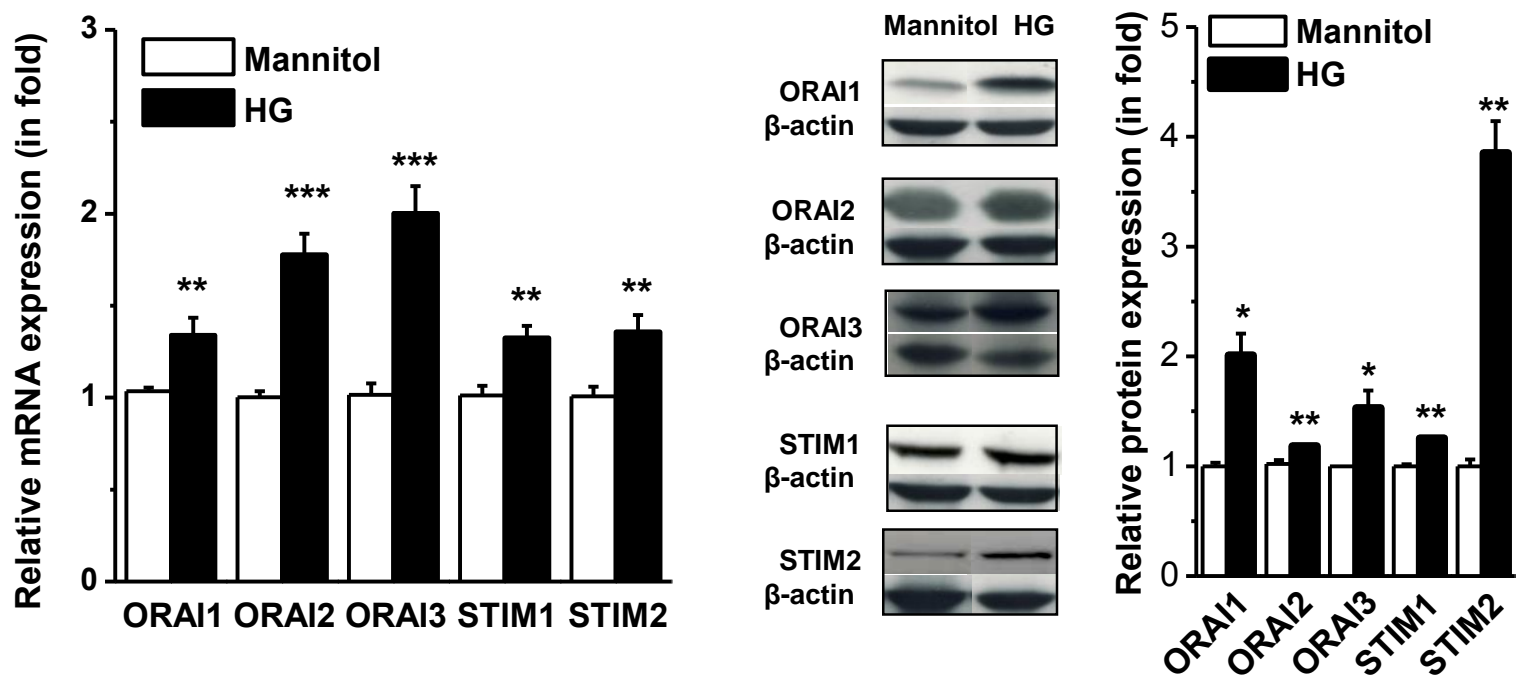

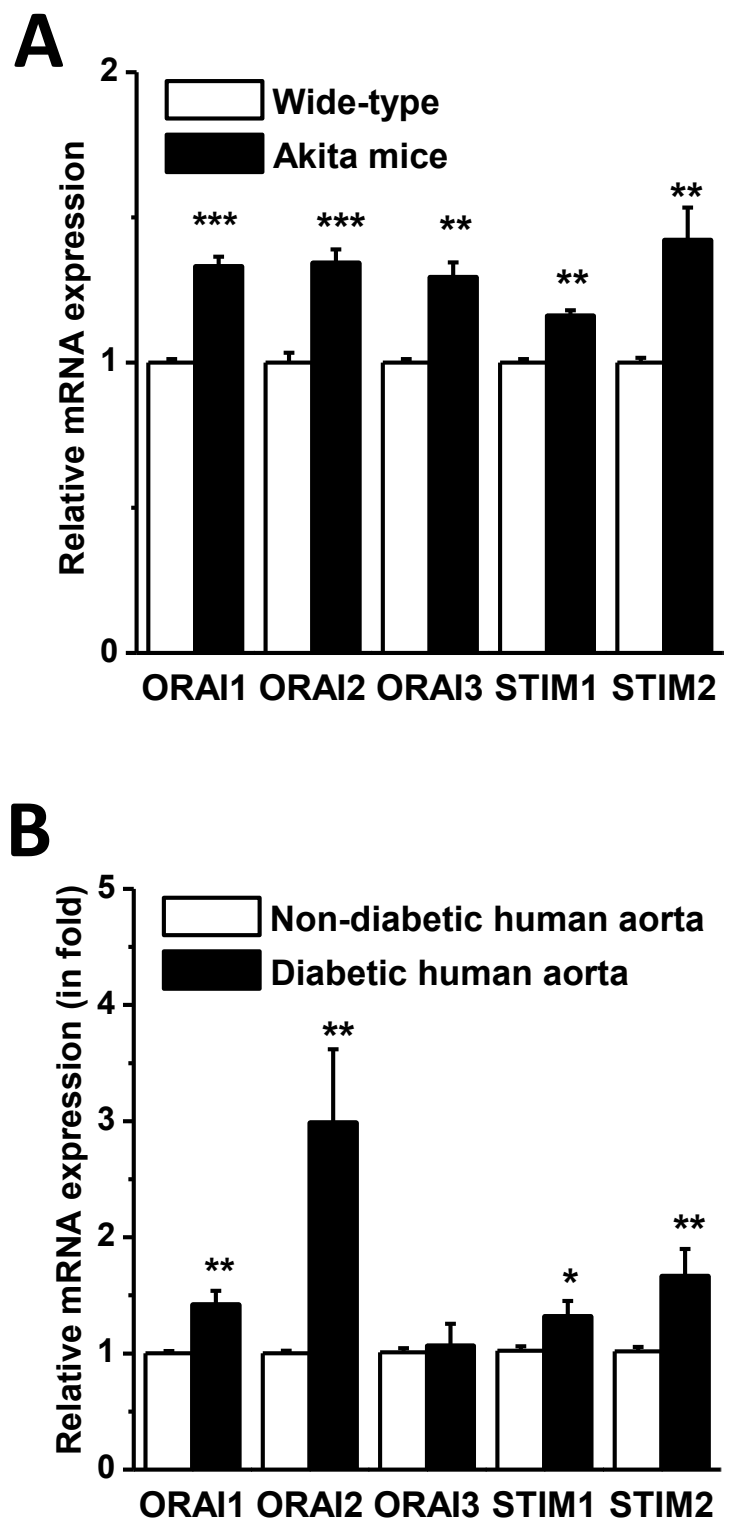

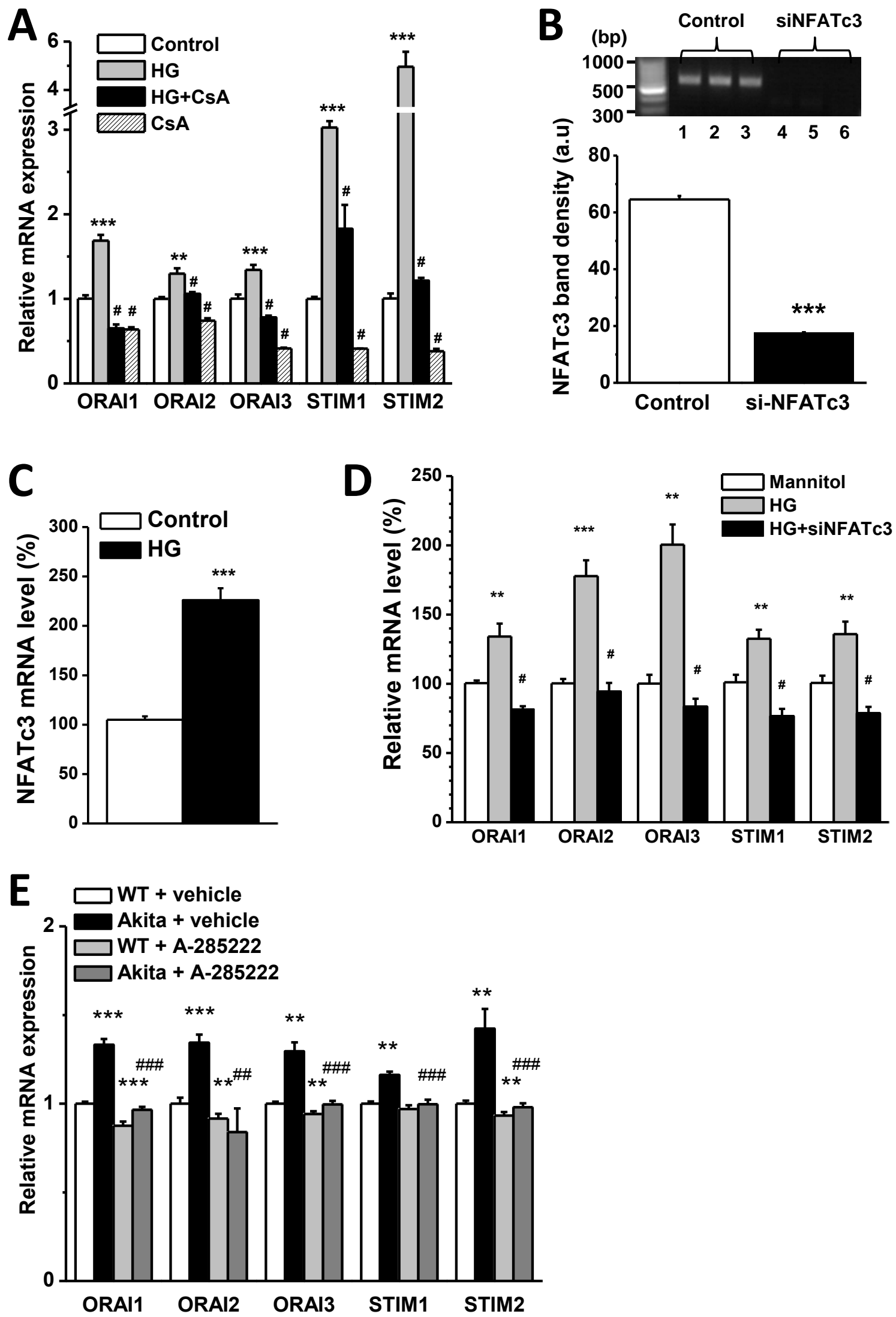

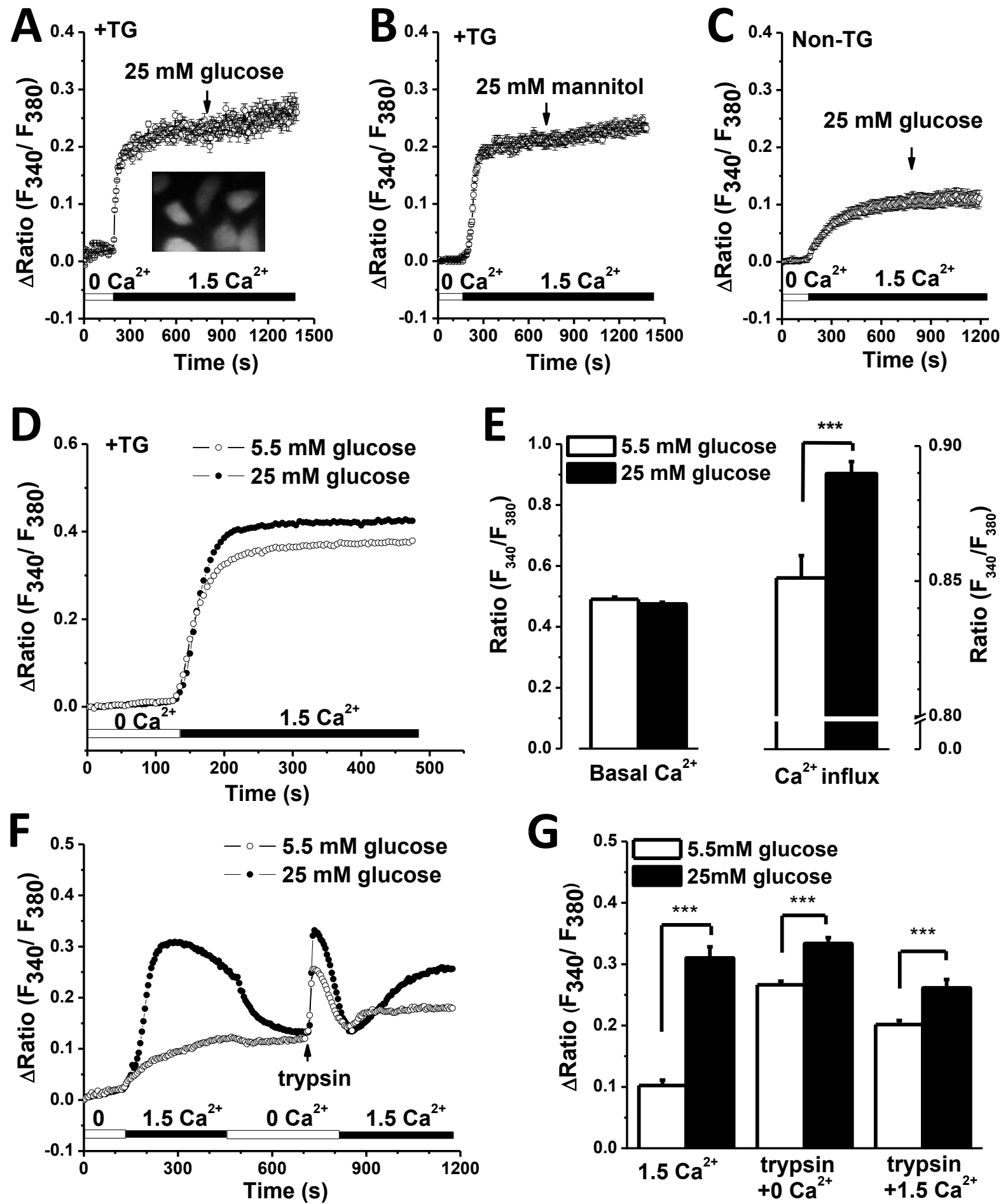

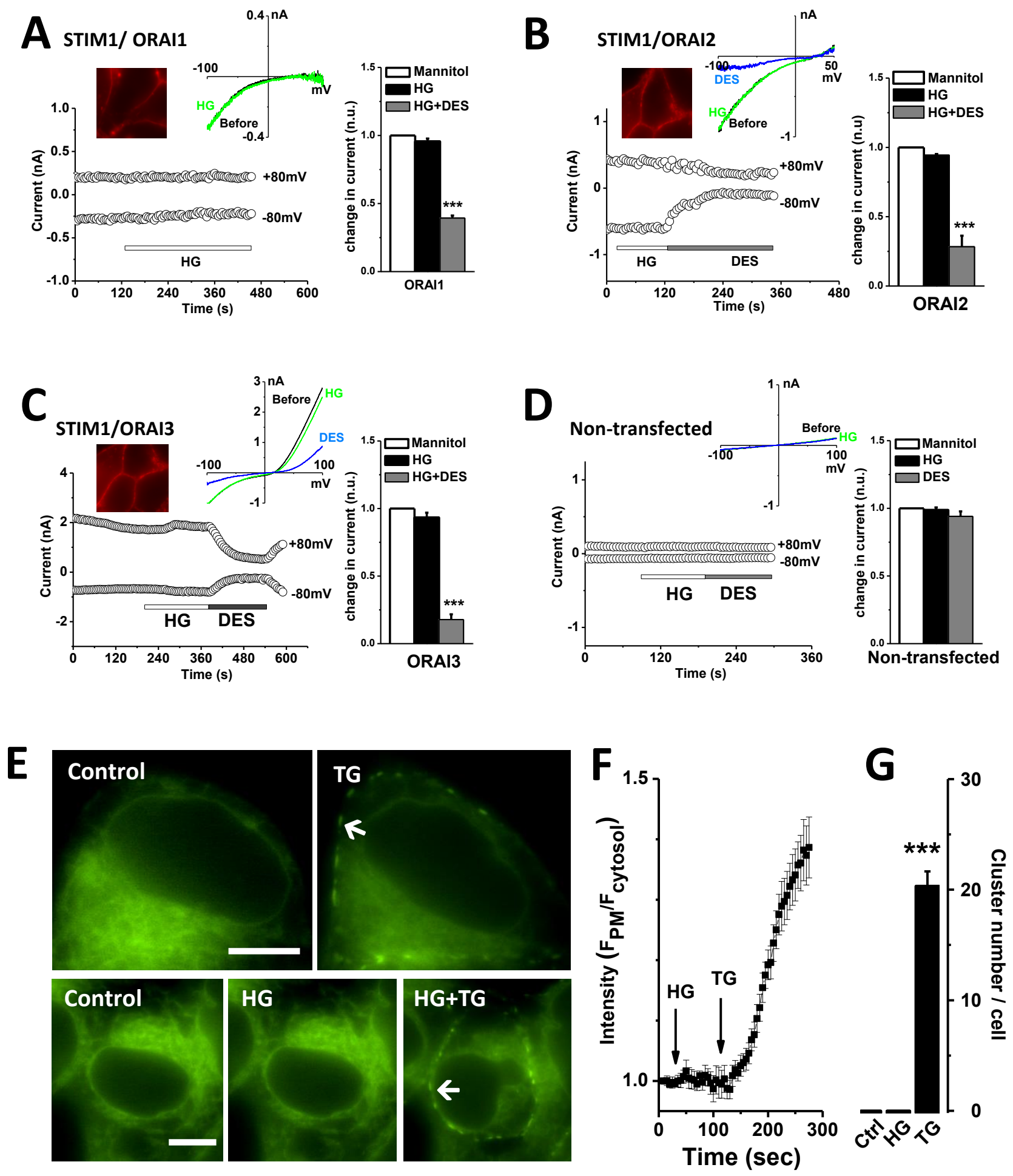
J Mol Med 2015

\section{High Glucose Enhances Store-Operated Calcium Entry by Upregulating ORAI/STIM} via Calcineurin-NFAT Signalling

Nikoleta Daskoulidou ${ }^{1}$, Bo Zeng ${ }^{1}$, Lisa M. Berglund ${ }^{2}$, Hongni Jiang ${ }^{1}$, Gui-Lan Chen ${ }^{1}$, Olga Kotova $^{2}$, Sunil Bhandari ${ }^{3}$, James Ayoola ${ }^{1}$, Steven Griffin ${ }^{4}$, Stephen L. Atkin ${ }^{1}$, Maria F Gomez ${ }^{2}$, Shang-Zhong $\mathrm{Xu}^{1 *}$

${ }^{1}$ Centre for Cardiovascular and Metabolic Research, Hull York Medical School, University of Hull, HU6 7RX, UK; ${ }^{2}$ Department of Clinical Sciences in Malmö, Lund University, Sweden; ${ }^{3}$ Department of Renal Medicine and Hull York Medical School, Hull Royal Infirmary, Hull and East Yorkshire Hospitals NHS Trust, UK; ${ }^{4}$ Department of Cardiac Surgery, Castle Hill Hospital, Hull and East Yorkshire Hospitals NHS Trust, UK
A
EA.hy926
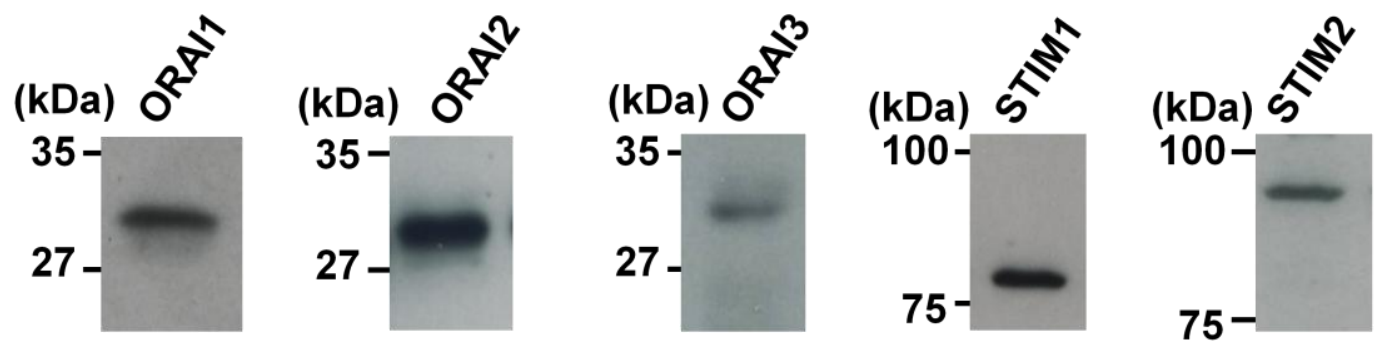

\section{LIMA}
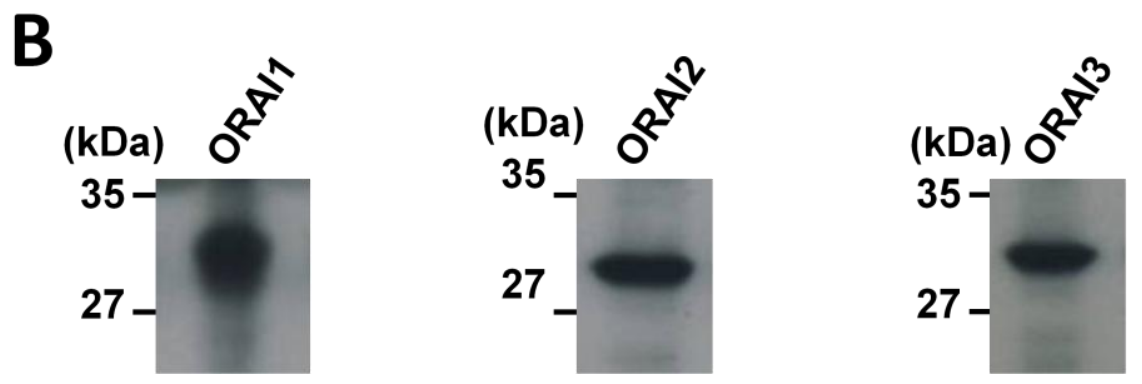

Supplementary Fig. 1. ORAIs and STIMs in human blood vessels and vascular cells. A, The protein bands for ORAI1, ORAI2, ORAI3, STIM1 and STIM2 were detected by Western blotting in EA.hy926 cells. B, ORAI1-3 detected in human left internal mammary artery (LIMA). 

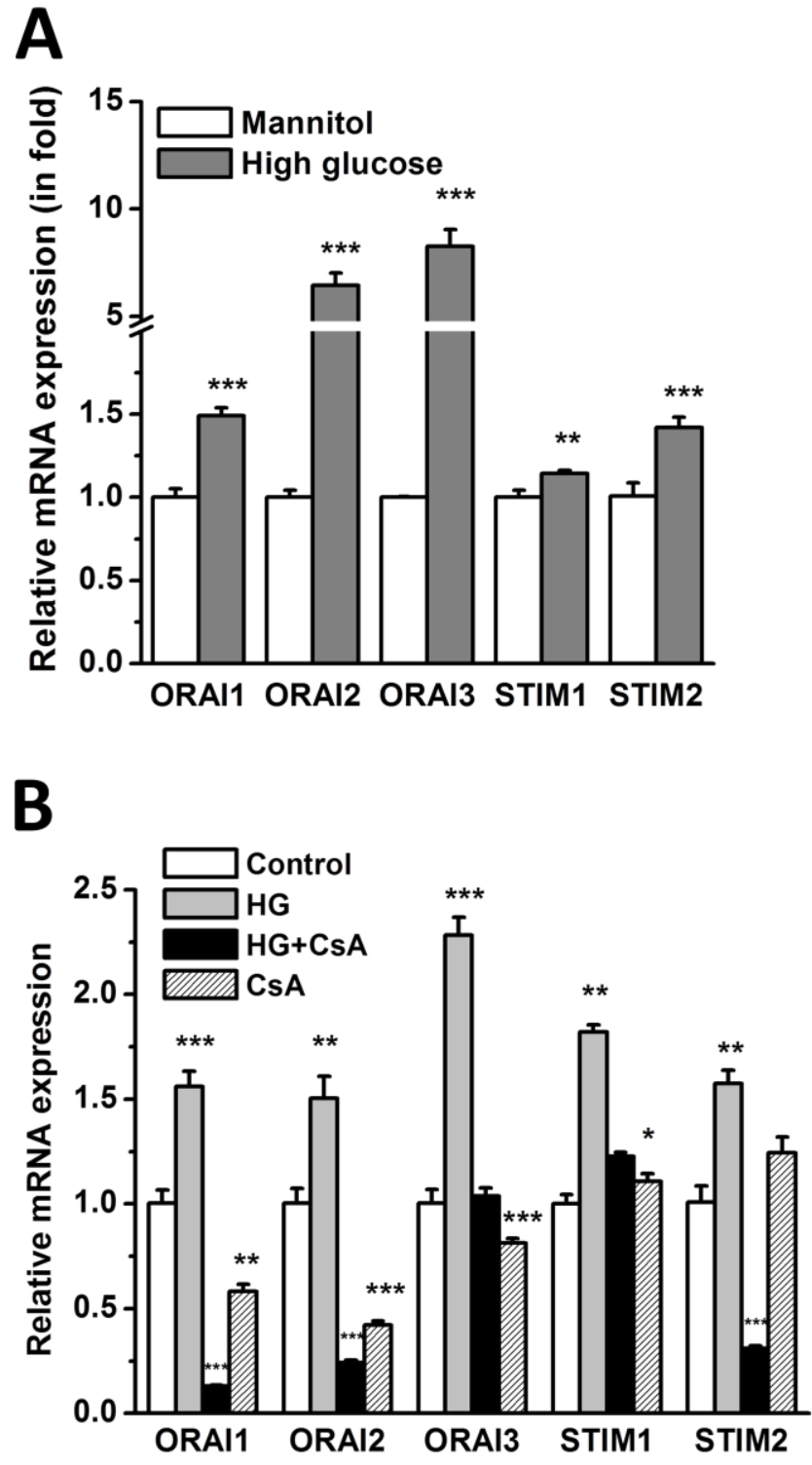

Supplementary Fig. 2. ORAI and STIM expression regulated by high glucose and $\mathrm{Ca}^{2+}$ calcineurin inhibitor in rat aortic smooth muscle cells. A, The mRNA level quantified by real-time PCR in rat aortic smooth muscle cells after treatment with high glucose $(25 \mathrm{mM})$, the mannitol $(19.5 \mathrm{mM})$ plus $5.5 \mathrm{mM}$ glucose as equal osmolarity control $(n=3$ for each group). B, The mRNA level in rat aortic smooth muscle cells treated with high glucose (25 $\mathrm{mM})$, cyclosporin A (CsA, $200 \mathrm{nM})$, and high glucose plus CsA for $48 \mathrm{~h}(n=3$ for each group). $\beta$-actin was used for relative quantification and triplicate reactions were set for each sample detection. $* P<0.05, * * P<0.01, * * * P<0.001$. 


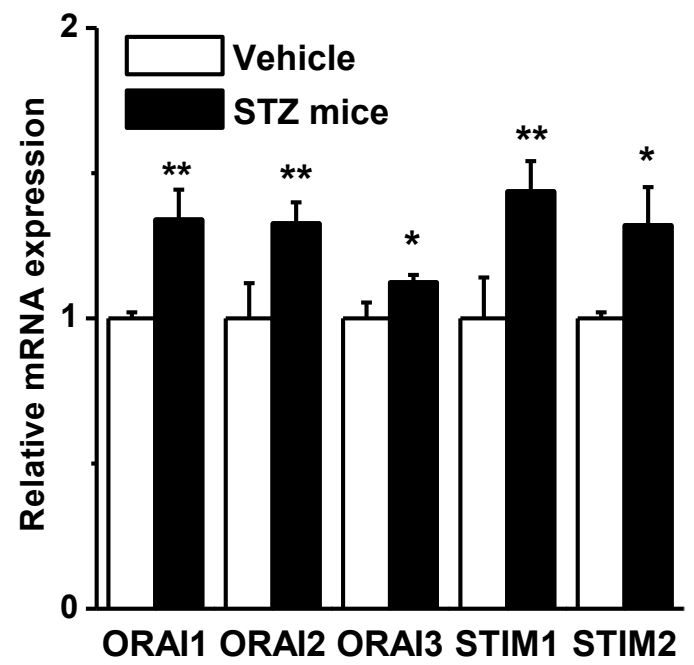

Supplementary Fig. 3. ORAI and STIM expression in streptozotocin (STZ)-induced diabetic mice A, ORAI and STIM expression in STZ-induced diabetic mice $(n=6)$, the mice injected with vehicle as control group. The mRNA levels of ORAIs and STIMs detected by real-time PCR in the aorta samples. Triplicate RT-PCR reactions were performed for each sample. $* P<0.05 ; * * P<0.01$. 
Supplementary Table 1. Primer sequences for RT-PCR

\begin{tabular}{|c|c|c|c|c|c|c|c|}
\hline Gene & Species & Accession No & $\mathbf{F} / \mathbf{R}$ & Primer sequence (5' to 3') & $\begin{array}{c}\mathbf{T}_{\mathbf{m}} \\
\left({ }^{\circ} \mathbf{C}\right)\end{array}$ & Location & $\begin{array}{l}\text { Size } \\
\text { (bp) }\end{array}$ \\
\hline \multirow[t]{4}{*}{$\beta$-actin } & Human & NM_001101.3 & $\mathrm{F}$ & ACAGAGCCTCGCCTTTGC & 65.7 & $30-47$ & 211 \\
\hline & Human & NM_001101.3 & $\mathrm{R}$ & GGAATCCTTCTGACCCATGC & 65.7 & $240-221$ & \\
\hline & Mouse & NM_007393.3 & $\mathrm{F}$ & TGTTACCAACTGGGACGACA & 60 & $304-324$ & 165 \\
\hline & Mouse & NM_007393.3 & $\mathrm{R}$ & GGGGTGTTGAAGGTCTCAAA & 59.94 & $468-449$ & \\
\hline \multirow[t]{3}{*}{ ORAI1 } & Human & NM_032790 & $\mathrm{F}$ & AGGTGATGAGCCTCAACGAG & 70.1 & $378-397$ & 238 \\
\hline & Human & NM_032790 & $\mathrm{R}$ & CTGATCATGAGCGCAAACAG & 69.5 & $615-596$ & \\
\hline & Rat & NM_001013982 & $\mathrm{R}$ & CTGATCATGAGGGCGAACAG & 65.8 & $491-510$ & \\
\hline \multirow[t]{4}{*}{ ORAI2 } & Human & NM_001126340 & $\mathrm{F}$ & CATAAGGGCATGGATTACCG & 66.7 & $296-315$ & 210 \\
\hline & Human & NM_001126340 & $\mathrm{R}$ & CGGGTACTGGTACTGCGTCT & 67.8 & $505-486$ & \\
\hline & Mouse & NM_178751.3 & $\mathrm{F}$ & CACAAGGGCATGGATTACCG & 67.3 & $193-212$ & 210 \\
\hline & Mouse & NM_178751.3 & $\mathrm{R}$ & AGGGTACTGGTACTTGGTCT & 56.6 & $402-383$ & \\
\hline \multirow[t]{6}{*}{ ORAI3 } & Human & NM_152288.2 & $\mathrm{F}$ & GGCTACCTGGACCTCATGG & 58.9 & 306-324 & 176 \\
\hline & Human & NM_152288.2 & $\mathrm{R}$ & GGTGGGTACTCGTGGTCACT & 58.3 & $462-481$ & \\
\hline & Mouse & NM_198424 & $\mathrm{F}$ & GGCTACCTGGACCTTATGG & 60.9 & $274-292$ & 176 \\
\hline & Mouse & NM_198424 & $\mathrm{R}$ & GGTGGGTATTCATGATCGTT & 61.1 & $449-430$ & \\
\hline & Rat & NM_001014024 & $\mathrm{F}$ & GGCTACCTCGACCTTATGG & 61.1 & $253-271$ & 176 \\
\hline & Rat & NM_001014024 & $\mathrm{R}$ & GGTGGGTATTCATGATCGCT & 63.7 & $409-428$ & \\
\hline \multirow[t]{4}{*}{ STIM1 } & Human & NM_003156 & $\mathrm{F}$ & TGTGGAGCTGCCTCAGTATG & 58.41 & $995-1014$ & 183 \\
\hline & Human & NM_003156 & $\mathrm{R}$ & AAGAGAGGAGGCCCAAAGAG & 58.47 & $1177-1158$ & \\
\hline & Mouse & NM_009287 & $\mathrm{F}$ & TGTGGAGCTGCCACAGTATG & 65.1 & $1024-1042$ & 182 \\
\hline & Mouse & NM_009287 & $\mathrm{R}$ & AAGAGAGGAGGCCCAAACAG & 64.5 & $1205-1186$ & \\
\hline \multirow[t]{4}{*}{ STIM2 } & Human & NM_020860 & $\mathrm{F}$ & CAGCCATCTGCACAGAGAAG & 58.12 & $857-876$ & 202 \\
\hline & Human & NM_020860 & $\mathrm{R}$ & AGGTTCGTGCACTGCTATCC & 58.75 & $1058-1039$ & \\
\hline & Mouse & NM_001081103 & $\mathrm{F}$ & TAGTCACCTGCACAGAGAAG & 58.2 & $688-707$ & 202 \\
\hline & Mouse & NM_001081103 & $\mathrm{R}$ & AGTTTCATGAACTGCTATCC & 55.8 & $889-870$ & \\
\hline
\end{tabular}


Supplementary Table 2. Blood glucose level and body weight in type 1 diabetic mouse models

\begin{tabular}{|c|c|c|c|c|c|c|}
\hline & $\mathrm{n}$ & Start & Final & $\mathrm{n}$ & Start & Final \\
\hline \multicolumn{4}{|c|}{ Vehicle } & \multicolumn{3}{|c|}{ Streptozotocin } \\
\hline Blood glucose (mM) & 6 & $9.11 \pm 0.33$ & $9.21 \pm 0.39$ & 6 & $7.99 \pm 0.28$ & $21.48 \pm 1.2 * * *$ \\
\hline \multirow[t]{2}{*}{ Weight start (g) } & 6 & $23.91 \pm 1.6$ & $31.30 \pm 1.00$ & 6 & $22.20 \pm 1.3$ & $26.49 \pm 0.62 * * *$ \\
\hline & \multicolumn{3}{|c|}{ Wide-type } & & \multicolumn{2}{|c|}{ Akita mice } \\
\hline Blood glucose $(\mathrm{mM})$ & 6 & $7.99 \pm 0.99$ & $8.01 \pm 1.27$ & 6 & $21.90 \pm 1.91$ & $21.38 \pm 1.92 * * *$ \\
\hline Weight start (g) & 6 & $18.29 \pm 0.42$ & $18.86 \pm 0.73$ & 6 & $18.00 \pm 0.75$ & $18.71 \pm 0.80$ \\
\hline
\end{tabular}

Note: Comparison between the control (vehicle or wild-type) and streptozotocin-treated or Akita mice group. *** $P<0.001$. 